\title{
The role of calcium homeostasis remodeling in inherited cardiac arrhythmia syndromes
}

\author{
Shanna Hamilton $^{1} \cdot$ Roland Veress $^{1} \cdot$ Andriy Belevych $^{1} \cdot$ Dmitry Terentyev $^{1}$ (D \\ Received: 7 October 2020 / Revised: 8 December 2020 / Accepted: 10 December 2020 / Published online: 6 January 2021 \\ (C) The Author(s) 2021
}

\begin{abstract}
Sudden cardiac death due to malignant ventricular arrhythmias remains the major cause of mortality in the postindustrial world. Defective intracellular $\mathrm{Ca}^{2+}$ homeostasis has been well established as a key contributing factor to the enhanced propensity for arrhythmia in acquired cardiac disease, such as heart failure or diabetic cardiomyopathy. More recent advances provide a strong basis to the emerging view that hereditary cardiac arrhythmia syndromes are accompanied by maladaptive remodeling of $\mathrm{Ca}^{2+}$ homeostasis which substantially increases arrhythmic risk. This brief review will focus on functional changes in elements of $\mathrm{Ca}^{2+}$ handling machinery in cardiomyocytes that occur secondary to genetic mutations associated with catecholaminergic polymorphic ventricular tachycardia, and long QT syndrome.
\end{abstract}

Keywords Calcium-dependent arrhythmia $\cdot$ Calcium homeostasis remodeling $\cdot$ Heart failure $\cdot$ Catecholaminergic polymorphic ventricular tachycardia · Long QT syndrome

\section{Introduction}

Cardiac contractility relies on the coordinated actions of intracellular $\mathrm{Ca}^{2+}$ cycling machinery in cardiomyocytes, including the sarcoplasmic reticulum (SR) $\mathrm{Ca}^{2+}$ release channel ryanodine receptor ( $\mathrm{RyR} 2$ ), $\mathrm{SR} \mathrm{Ca}^{2+} \mathrm{ATPase}$ (SERCa), the electrogenic plasmalemmal $\mathrm{Na}^{+} / \mathrm{Ca}^{2+}$ exchanger (NCX1), and the L-Type $\mathrm{Ca}^{2+}$ channel (LTCC) $[6,28]$. The tight control of coupling between excitation and $\mathrm{Ca}^{2+}$-dependent contraction of the heart is essential for meeting variable metabolic demands of the body. Inherited mutations in ion channels, auxiliary or structural proteins that alter cardiac cell electrophysiology or cardiac conduction, manifesting as arrhythmia syndromes, usually do not dramatically change basal cardiac contractile function [28]. This strongly suggests that adaptive remodeling of intracellular $\mathrm{Ca}^{2+}$ transport machinery occurs to

This article is part of the special issue on Calcium Signal Dynamics in Cardiac Myocytes and Fibroblasts: Mechanisms in Pflügers Archiv-European Journal of Physiology

Dmitry Terentyev

dmitry.terentyev@osumc.edu

1 Department of Physiology and Cell Biology, Davis Heart and Lung Research Institute, Wexner Medical Center, The Ohio State University, Columbus, OH, USA ensure long-term survival. However, under certain conditions such as stress, functional changes in $\mathrm{Ca}^{2+}$ handling proteins become problematic, exacerbating arrhythmia burden.

\section{Bidirectional control of SR $\mathrm{Ca}^{2+}$ release and sarcolemmal ion fluxes}

During early stages of the action potential (AP), a small amount of $\mathrm{Ca}^{2+}$ enters the myocyte via LTCCs and NCX1 in reverse mode. This small amount of $\mathrm{Ca}^{2+}$ is sufficient to activate RyR2s, resulting in a massive $\mathrm{Ca}^{2+}$ release from the main intracellular storage organelle, the SR. Released $\mathrm{Ca}^{2+}$ instantaneously feeds back on sarcolemmal ionic conductance, playing important roles in shaping AP [6]. The large increase in subsarcolemmal $\left[\mathrm{Ca}^{2+}\right]$ during the $\mathrm{Ca}^{2+}$ transient, which can reach 20-40 $\mu \mathrm{M}$ at its peak [71], effectively inactivates LTCCs, reducing the depolarizing force of $\mathrm{Ca}^{2+}$ current $\left(I_{\mathrm{Ca}}\right)$. At the same time, activation of electrogenic NCX1 in forward mode, which injects $3 \mathrm{Na}^{+}$for each $1 \mathrm{Ca}^{2+}$ removed from the cell, contributes to depolarization and prolongs AP duration (APD). In addition, $\left[\mathrm{Ca}^{2+}\right]_{i}$ can shape AP via enhancement of $\mathrm{Ca}^{2+}$-dependent $\mathrm{K}^{+}$and $\mathrm{Cl}^{-}$channels promoting repolarization and shortening APD [39, 40]. Therefore, depending on the specific composition of ionic fluxes, $\mathrm{SR} \mathrm{Ca}^{2+}$ release can either prolong or shorten APD. 
This is especially well illustrated during APD alternans; beat to beat alterations in APD [27]. Concordant alternans exhibit long APD when $\mathrm{SR} \mathrm{Ca}^{2+}$ release is large and short when $\mathrm{Ca}^{2+}$ release in small. During discordant alternans, this relationship is reversed. Increase in depolarizing $I_{\mathrm{Ca}}$ and $I_{\mathrm{NCX}}$ and decrease in repolarizing currents along with untimely RyR2-mediated $\mathrm{Ca}^{2+}$ release cause arrhythmogenic disturbances in membrane potential called delayed or early afterdepolarizations (DADs and EADs, respectively) that underlie triggered activity at the whole heart level [64].

Pharmacological interventions to rapidly change activity of sarcolemmal ion channels and transporters are known to elicit profound effects on SR $\mathrm{Ca}^{2+}$ release [6]. Pharmacological inhibition of repolarizing $\mathrm{K}^{+}$channels to prolong APD permits larger $\left[\mathrm{Ca}^{2+}\right]$ influx via LTCCs, resulting in much larger $\mathrm{Ca}^{2+}$ release. Enhancement of $\mathrm{Na}^{+}$conductance increases depolarization and induces rapid accumulation of $\mathrm{Na}^{+}$in the cell, and consequently drives $\mathrm{Ca}^{2+}$ "overload" via inhibition of forward mode NCX1. This can result in increased amplitude of $\mathrm{Ca}^{2+}$ release during systole and generation of spontaneous $\mathrm{Ca}^{2+}$ waves during diastole. However, genetic mutations modifying the same ion fluxes often produce minimal changes in net intracellular $\mathrm{Ca}^{2+}$ cycling under basal conditions both in human patients and animal models. Furthermore, even mutations in components of $\mathrm{SR} \mathrm{Ca}^{2+}$ release machinery are relatively well tolerated and manifestation in the form of deadly arrhythmias is a rare, primarily occurring under stress $[15,41$, 69]. Therefore, constant change in electrical or mechanical properties, either acquired or inherited, or even change in activity of a single member of $\mathrm{Ca}^{2+}$ handling machinery must cause secondary adaptive changes that allow preservation of a primary heart function, i.e., contractility for as long as possible.

\section{Balance of cellular $\mathrm{Ca}^{2+}$ fluxes}

At steady state, the amount of $\mathrm{Ca}^{2+}$ entering the cell via LTCCs during each beat must be equal to $\mathrm{Ca}^{2+}$ extruded by NCX1 [28]. Similarly, the amount of $\mathrm{Ca}^{2+}$ released from the SR by RyR2s must be matched by SERCa-mediated sequestration. Given the key function of rhythmic $\mathrm{Ca}^{2+}$ cycling in cardiomyocytes, there are several self-regulation mechanisms to maintain steady state. The most powerful mechanism is based on the ability of RyR2 to sense $\mathrm{Ca}^{2+}$ not only on the cytosolic side but also in the SR lumen as well. A decrease in luminal $\left[\mathrm{Ca}^{2+}\right]$ during the $\mathrm{Ca}^{2+}$ transient directly or indirectly forces the cessation of RyR2 cluster activity, eliciting the termination of SR $\mathrm{Ca}^{2+}$ release [30, 73, 75]. Increased RyR2s activity leads to diminished $\mathrm{SR} \mathrm{Ca}^{2+}$ content given the loss of $\mathrm{Ca}^{2+}$ during diastole, named SR $\mathrm{Ca}^{2+}$ leak [28]. However, this has a limited impact on the amplitude of systolic $\mathrm{Ca}^{2+}$ release because more active RyR2s remain open at substantially lower intra-SR $\left[\mathrm{Ca}^{2+}\right]$. As a result, RyR2-mediated SR $\mathrm{Ca}^{2+}$ leak must be sufficiently large to reduce $\mathrm{Ca}^{2+}$ transient amplitude. Notably, enhancement of RyR2 activity is the most common finding throughout the whole spectrum of acquired cardiac diseases including heart failure (HF), myocardial infarct (MI), diabetic cardiomyopathy, and age-related cardiac dysfunction [31, 32, 60, 84].

Another important self-limiting mechanism is $\mathrm{Ca}^{2+}$-dependent inactivation of LTCCs [6]. Increased $I_{\mathrm{Ca}}$ significantly increases myocyte loading, with $\mathrm{Ca}^{2+}$ consequently increasing systolic SR $\mathrm{Ca}^{2+}$ release and thereby accelerating LTCC inactivation. Pharmacologically-mediated reduction in NCX1 activity leads to similar effects on $\mathrm{SR} \mathrm{Ca}^{2+}$ release and LTCC inactivation [36], which might explain why NCX1 inhibitors do not produce massive $\mathrm{Ca}^{2+}$ overload when used to attenuate EADs and DADs that underlie triggered activity [64]. Importantly, when the metabolic demand of the body increases, such as during stress, self-regulatory mechanisms are overridden to increase cardiac contractility [6]. During stress, the catecholamine-induced increase in LTCCmediated $\mathrm{Ca}^{2+}$ influx and SERCa-mediated SR $\mathrm{Ca}^{2+}$ sequestration outpaces NCX1-mediated $\mathrm{Ca}^{2+}$ removal and RyR2mediated diastolic $\mathrm{Ca}^{2+}$ leak, reaching a new steady state with increased systolic $\mathrm{SR} \mathrm{Ca}^{2+}$ transient amplitude [28]. Failure to match the fluxes and deficiencies of self-regulatory mechanisms leads to impaired cardiac contractility and an enhanced propensity to $\mathrm{Ca}^{2+}$-dependent arrhythmia.

\section{Regulatory mechanisms of modulation of intracellular $\mathrm{Ca}^{2+}$ homeostasis}

As HF is accompanied by profound changes in ionic currents and increased arrhythmogenesis, it is likely there is a substantial overlap of mechanisms underlying the remodeling of $\mathrm{Ca}^{2+}$ homeostasis in hereditary arrhythmia syndromes. Years of research studying remodeling of $\mathrm{Ca}^{2+}$ handling in $\mathrm{HF}$ and other models of acquired cardiac disease have revealed a number of fundamental mechanisms affecting function of $\mathrm{Ca}^{2+}$ handling complexes. Increased NCX1 activity in HF has been attributed to increased expression levels and an indirect effect of cytosolic $\mathrm{Na}^{+} / \mathrm{Ca}^{2+}$ overload given increased late $\mathrm{Na}^{+}$current $\left(I_{\mathrm{NaL}}\right)[22,23,65]$. The expression levels of the $\alpha 1 \mathrm{c}$ pore forming subunit of LTCC are decreased in human HF [16, 80]. However, baseline $I_{\mathrm{Ca}}$ amplitude is not affected because PKA-dependent phosphorylation of the channel, which enhances channel activity, is increased. This results in reduced responsiveness of LTCC to $\beta$-adrenergic stimulation in HF. Depressed SERCa activity in HF has been ascribed to decreased expression levels and reduced phosphorylation of auxiliary negative SERCa regulator, phospholamban (PLB) $[14,35,79]$. Increased localized activity of Serine/Threonine phosphatase PP1 underlies hypo-phosphorylation of PLB in 
HF [14]. This interferes with the relief of PLB's inhibitory action on SERCa under basal conditions and during catecholaminergic stimulation. Likewise, changes in intracellular signaling cascades are involved in modulation of RyR2 activity in HF $[60,84]$. Enhanced PKA- and CaMKII-dependent phosphorylation increase RyR2 activity [1, 52]. Increased RyR2 phosphorylation has been attributed to the increased activity of kinases and the dissociation of opposing phosphatases PP1 and PP2a from the complex [1, 5, 47, 54]. In addition, changes in redox state, metabolism, mitochondrial function, and subcellular structural remodeling are thought to affect $\mathrm{Ca}^{2+}$ homeostasis as well $[60,84]$. Recent advances provide growing evidence that many of these mechanisms are similarly involved in $\mathrm{Ca}^{2+}$ handling remodeling in hereditary ventricular arrhythmia syndromes.

\section{Inherited cardiac arrhythmia syndromes and $\mathrm{Ca}^{2+}$ homeostasis remodeling}

\section{Catecholaminergic polymorphic ventricular tachycardia}

Catecholaminergic polymorphic ventricular tachycardia (CPVT) is a highly malignant arrhythmogenic disorder, manifesting as polymorphic or bidirectional VT after emotional stress or exercise in patients with structurally normal hearts $[15,82]$. Mutations linked to CPVT are typically associated with gain of function of RyR2 SR $\mathrm{Ca}^{2+}$ release complex that promotes arrhythmogenic spontaneous $\mathrm{SR} \mathrm{Ca}^{2+}$ release (Fig. 1). CPVT type 1 is primarily caused by gain of function mutations in RyR2. CPVT types $2-6$ have been attributed to loss-of function mutations in auxiliary proteins regulating RyR2 activity. CPVT types 2 and 5 are caused by mutations in SR luminal proteins calsequestrin (CASQ2) and triadin (TRDN) respectively [15], and characterized by loss of control of RyR2 complex activity by luminal $\mathrm{Ca}^{2+}$. Mutations in calmodulin (Calm) 1 and 3 (underlying CPVT types 4 and 6, respectively) and more recently Calm2, which tether to RyR2 at the cytosolic side, interfere with the complex responsiveness to activation by cytosolic $\mathrm{Ca}^{2+}$ [82]. CPVT type 3 has been linked to mutations in trans-2,3-enoyl-CoA reductaselike (TECRL) $[24,59]$, an enzyme residing primarily in the $\mathrm{SR}$, but the mechanism of action is yet to be defined.

\section{$\mathrm{Ca}^{2+}$ homeostasis and post-translational remodeling}

Data accumulated over almost 20 years suggest that CPVT mutations causative of RyR2-mediated SR $\mathrm{Ca}^{2+}$ leak have minimal impact on $\mathrm{Ca}^{2+}$ transient amplitude under basal conditions. Major changes become obvious under $\beta$-adrenergic stimulation, including diminished $\mathrm{Ca}^{2+}$ transient amplitude and, importantly, the incidence of spontaneous diastolic

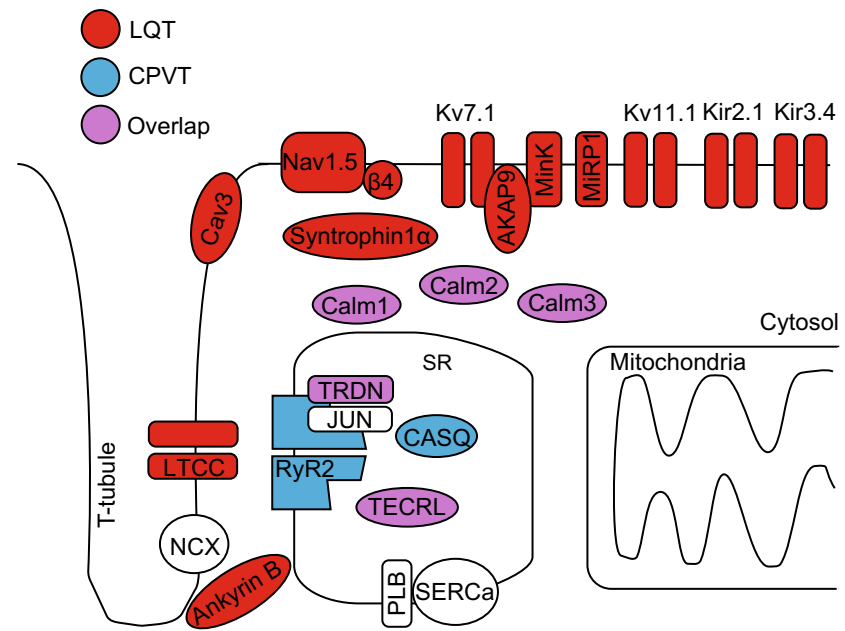

Fig. 1 Proteins of cardiac excitation-contraction coupling associated with long QT syndrome or catecholaminergic polymorphic ventricular tachycardia, caused by pathogenic mutation. Proteins with mutations associated with long QT syndrome are colored red; proteins with mutations associated with CPVT are colored blue; proteins with mutations that can cause long QT syndrome or CPVT are colored purple. Kv7.1; KCNQ1 gene, $\alpha$-subunit of $I_{\mathrm{Ks}}$ channel, mutations underlie LQT1. Kv11.1; $\mathrm{KCNH} 2$ gene, $\alpha$-subunit of $I_{\mathrm{Kr}}$ channel, mutation underlies LQT2. Nav1.5; SCN5a gene, $\alpha$-subunit of $I_{\mathrm{Na}}$ channel, mutations underlie LQT3. Ankyrin B; ANK2 gene, functions as an adaptor protein, mutations underlie LQT4. minK; KCNE1 gene, $\beta$-subunit of $I_{\mathrm{Ks}}$ channel, mutations underlie LQT5. MiRP1; KCNE2 gene, $\beta$-subunit of $I_{\mathrm{Kr}}$ channel, mutations underlie LQT6. Kir2.1; KCNJ2 gene, $\alpha$-subunit of $I_{\mathrm{K} 1}$ channel, mutations underlie LQT7. LTCC; CACNA1C gene, mutations in $\alpha$ subunit of $I_{\mathrm{Ca}, \mathrm{L}}$ channel underlie LQT8 (Timothy syndrome). Cav3; $C A V 3$ gene, caveolin-3 protein is a component of caveolae that colocalizes with Nav1.5, mutations underlie LQT9. $\beta 4$; $S C N 4 B$ gene, $\beta$ subunit of $I_{\mathrm{Na}}$ channel, mutation underlies LQT10. AKAP9; AKAP9 gene, protein mediates Kv7.1 phosphorylation, mutations underlie LQT11. Syntrophin $1 \alpha ; S N T A 1$ gene, protein regulates $I_{\mathrm{Na}}$ function, mutations underlie LQT12. Kir3.4; KCNJ5 gene, subunit of $K_{\mathrm{ACh}}$ channel, mutations underlie LQT13. Calm1; CALM1 gene, calmodulin serves as a $\mathrm{Ca}^{2+}$-binding messenger protein, mutations underlie LQT14 and CPVT4. Calm2; CALM2 gene, mutations underlie LQT15 and phenotype overlaps with CPVT. Calm3; CALM3 gene, mutations underlie LQT16 and CPVT6. TRDN; TRDN gene, triadin is an accessory protein of RyR2, mutations underlie LQT17, and phenotype overlaps with CPVT5. TECRL; TECRL gene, trans-2,3-enoyl-CoA reductase like protein belongs to the steroid 5-alpha reductase family, mutations underlie CPVT3 and LQT18. RyR2; RYR2 gene, ryanodine receptor is the major sarcoplasmic reticulum $\mathrm{Ca}^{2+}$ release channel, mutations underlie CPVT1. CASQ; CASQ2 gene, calsequestrin2 is an accessory protein of RyR2, mutations underlie CPVT2. JUN; ASPH gene, junctin is an accessory protein of RyR2, no CPVT or LQT-associated mutations reported. SERCa; ATP2A2 gene, protein functions as the sarcoplasmic reticulum $\mathrm{Ca}^{2+}$-ATPase, no CPVT or LQT-associated mutations reported. PLB; $P L N$ gene, phospholamban functions as an inhibitory protein of SERCa, no CPVT or LQT-associated mutations reported

$\mathrm{Ca}^{2+}$ waves that drive EADs and DADs [15, 41]. More direct treatment strategies targeting the RyR2 macromolecular complex that have been successfully tested using animal models include (1) pharmacological inhibition of RyR2 (dantrolene [44], flecainide [81], JTV-519 [48, 83]); (2) overexpression of WT form of accessory protein (i.e., CASQ) to reduce impact 
of a recessive CPVT mutation [52]; (3) gene editing-mediated disruption or siRNA-mediated suppression of a dominant CPVT mutation disease-causing allele [8, 62]; and (4) expression of exogenous plant form of regulatory protein CALM with enhanced ability to stabilize RyR2 [50].

Importantly, several indirect approaches to reduce arrhythmogenicity and improve $\mathrm{Ca}^{2+}$ homeostasis in CPVT models were also proven to be successful. For example, the Radwanski group reported that inhibition of late $\mathrm{Na}^{+}$current is sufficient to alleviate catecholamine-induced arrhythmia in CASQ2-R33Q knock in (KI) CPVT mice [67]. Liu et al. [49] demonstrated that CaMKII inhibition with pharmacological inhibitor KN93 or inhibitory peptide AIP reduces spontaneous $\mathrm{SR} \mathrm{Ca}^{2+}$ release and thereby triggered activity in the form of DADs in cardiomyocytes from RyR2-R4496C ${ }^{(+/-)} \mathrm{KI}$ CPVT mice. CaMKII inhibition with KN93 completely alleviated catecholamine-induced sustained ventricular tachyarrhythmia in this model. The efficacy of CaMKIIsuppression-based therapy was further validated in experiments using CPVT patient-derived iPSCs and CPVT mice with AAV-mediated overexpression of AIP [7, 25]. Moreover, experiments using CRISPR/CAS9 technology recently showed that phosphorylation at RyR2 CaMKII-specific site Serine-2814 is necessary to reveal CPVT phenotype [63]. Experiments using isolated channels from a CPVT RyR2V2475 $\mathrm{F}^{(+-)}$KI mouse model showed that phosphorylation at PKA RyR2 phosphorylation site Serine-2030 is increased in response to PKA application, while phosphorylation of CaMKII site Serine-2814 was not changed under similar conditions [51]. Taken together, these findings raise the possibility that in CPVT RyR2 complex loses association with resident phosphatases PP1 and PP2A that counter local activities of PKA and CaMKII, the phenomenon described in $\mathrm{HF}[1,5]$.

\section{Mitochondrial dysfunction}

The information regarding CPVT-related changes in mitochondria SR-communication remains limited. Electron microscopy studies have revealed subcellular structural changes in the RyR2-A4860G ${ }^{(+-)}$mouse model of CPVT, suggesting altered tunneling and thereby communication patterns between jSR and mitochondria [45]. To our knowledge, there are no reports yet as to whether there are differences in expression levels of mitofusins, the scaffolding proteins that tether SR and mitochondria [68]; and mitochondrial $\mathrm{Ca}^{2+}$ handling proteins including mitochondrial $\mathrm{Na}^{+} / \mathrm{Ca}^{2+}$ exchanger (NCLX), and partners of mitochondrial $\mathrm{Ca}^{2+}$ uniporter (MCU), including Micu1, Micu2, and EMRE [29]. Our recent study [34] showed unchanged MCU expression and increased expression of MCU inhibitory paralog MCUb in CASQ2 KO CPVT mouse hearts. We demonstrated that disturbances in the RyR2 SR $\mathrm{Ca}^{2+}$ release complex profoundly affect mitochondrial function, causing excessive production of mitochondrial reactive oxygen species (ROS) such as superoxide and hydrogen peroxide $[10,34]$. The role of less reactive of the two, hydrogen peroxide, as a second messenger is well established [72]. Given it can diffuse several microns in the cell milieu from the source [56], mitochondria-derived $\mathrm{H}_{2} \mathrm{O}_{2}$ can reach RyR2 clusters which are situated at a distance as close as $20 \mathrm{~nm}$ in ventricular myocytes [19]. Increased mito-ROS emission results in oxidation of RyR2, further increasing its activity. Importantly, mito-ROS scavenging with the mitochondrial-targeted antioxidant mito-TEMPO reduced RyR2 oxidation, restored SR $\mathrm{Ca}^{2+}$ content, and reduced incidence of pro-arrhythmic spontaneous $\mathrm{Ca}^{2+}$ waves in $\beta$ adrenergic agonist-treated cardiomyocytes from the CASQ2 knock out (KO) CPVT mouse model [34]. Earlier studies using a canine model of tachypacing-induced HF demonstrated increased RyR2 oxidation in ventricular cardiomyocytes [76]. Furthermore, mito-ROS scavenging using mitoTEMPO attenuated RyR2 oxidation and arrhythmogenic spontaneous $\mathrm{Ca}^{2+}$ release in a rabbit model of aging [18]. Together, these studies establish a direct link between RyR2 complex hyperactivity, RyR2 oxidation, and excessive mitochondrial-mediated ROS production, a common phenomenon in both hereditary CPVT and acquired cardiac diseases.

Of note, there is ongoing debate whether mitochondria can shape intracellular $\mathrm{Ca}^{2+}$ cycling serving as a $\mathrm{Ca}^{2+}$ buffer, in addition to being source of ROS [61]. Interestingly, pharmacological enhancement of inner mitochondrial membraneresiding $\mathrm{Ca}^{2+}$ uniporter (MCU) complex, or outer mitochondrial membrane residing channel VDAC, reduced spontaneous $\mathrm{Ca}^{2+}$ release incidence in myocytes from CPVT mice [70]. However, this beneficial effect conflicts with recent data where pharmacological facilitation of mitochondria $\mathrm{Ca}^{2+}$ accumulation was shown to produce mito-ROS surge, exacerbating RyR2 hyperactivity and thereby spontaneous $\mathrm{Ca}^{2+}$ release [33]. Furthermore, analysis of temporal parameters of spontaneous $\mathrm{Ca}^{2+}$ waves in this work showed that both inhibition and facilitation of mitochondrial $\mathrm{Ca}^{2+}$ uptake have no discernible effects on wave propagation velocity, suggesting a minimal role of mitochondria as $\mathrm{Ca}^{2+}$ buffer in adult ventricular myocytes [33]. Changes in $\mathrm{Ca}^{2+}$ wave incidence and frequencies caused by facilitation and inhibition of mito- $\mathrm{Ca}^{2+}$ uptake reported in this manuscript were attributable to the changes in RyR2 oxidation levels by mito-ROS. These results are in line with the view accepted by several leading groups that mitochondria $\mathrm{Ca}^{2+}$ buffering ability in terminally differentiated VMs is very low in comparison to contractile apparatus or SERCa [4, 9, 28, 53].

\section{Subcellular structural remodeling}

Typically CPVT mutations do not cause structural remodeling of the heart [15]. However, there is a growing evidence of 
CPVT-associated changes in ventricular myocyte subcellular organization. The first indications of such phenomena have been obtained using CASQ2 KO CPVT mouse model where Knollmann et al. [43] documented dramatic increase in SR volume, potentially a compensatory change to preserve SR $\mathrm{Ca}^{2+}$ buffering capacity in the absence of CASQ2, a major luminal $\mathrm{Ca}^{2+}$ buffer. An elegant study from this group which followed demonstrated that $\mathrm{KO}$ of luminal accessory protein TRDN (to mimic CPVT-linked loss-of TRDN-function mutations) causes profound changes in RyR2 complexes and subcellular structural organization, leading to almost $50 \%$ loss of contacts between T-tubules and junctional SR [17]. Loss of contacts between T-tubules and jSR is a recurrent finding in HF $[12,16,74]$. Importantly, prevention of proteasomal degradation of misfolded proteins by an inhibitor of mannosidaseI kifunensine successfully reduced CPVT occurrence in TRDN-KO mice [13]. The loss of jSR-T-tubular contacts in TRDN KO cardiomyocytes results in reduced $\mathrm{Ca}^{2+}$-dependent inactivation of LTCCs, enhancing $\mathrm{Ca}^{2+}$ influx through the plasmalemma. Interestingly, later studies revealed that CPVT linked to TRDN mutations exhibit features consistent with long QT syndrome (LQTS) as well [2], which is not surprising given LTCC inactivation impairment. The overlap with LQTS was also noticed for CPVT TECRL loss-of function mutations manifested by QTc prolongation in patients under catecholaminergic surge [24,59].

Taken together, these works provide strong support for the concept that initial insult by CPVT mutations causes profound secondary changes in the following: (a) posttranslational control of RyR2 activity; (b) mitochondrial function; and (c) intracellular structural organization. Evidently, these secondary changes are key to revealing the arrhythmogenic phenotype in CPVT.

\section{LQT syndrome and $\mathrm{Ca}^{2+}$ release}

Long QT syndrome (LQTS) is a malignant arrhythmogenic disorder, characterized by QT prolongation accompanied with ventricular tachyarrhythmias typically in the form of torsade de pointes (TdP) and polymorphic VT [3, 15, 41, 69]. Arrhythmic events in LQTS usually occur in patients during emotional stress or exercise and less frequently during sleep. Mutations in three genes are responsible for the vast majority of LQTS cases in humans, namely KCNQ1 encoding Kv7.1 channel $\alpha$-subunit (LQT1, 35\% of cases), KCNH2 encoding Kv11.1 channel $\alpha$-subunit (LQT2, 30\% of cases), and SCN5A encoding Nav1.5 $\mathrm{Na}^{+}$channel $\alpha$-subunit (LQT3, $10 \%$ of cases). Loss-of-function $\mathrm{K}^{+}$channel mutations reduce repolarizing $\mathrm{K}^{+}$currents $I_{\mathrm{Ks}}$ (LQT1) and $I_{\mathrm{Kr}}$ (LQT2) leading to AP prolongation, similarly to gain-of-function LQT3 mutations in $\mathrm{Na}^{+}$channel which promote depolarization. As mentioned above, acute pharmacologically induced AP prolongation in ventricular myocytes leads to severe intracellular $\mathrm{Ca}^{2+}$ overload, enhancing both systolic and arrhythmogenic spontaneous SR $\mathrm{Ca}^{2+}$ release. Increased $\mathrm{Ca}^{2+}$ transient amplitude increases cardiac contraction. However, a robust increase in cardiac function is not a common observation in inherited LQTS. Available literature documents mechanical changes in human LQTS patients and large animal models consistent with diastolic dysfunction [41, 69], which implies adaptive remodeling of $\mathrm{Ca}^{2+}$ homeostasis occurs. Given HF is accompanied by a loss of repolarizing currents and increase in $I_{\mathrm{NaL}}$, the mechanisms underlying changes in $\mathrm{Ca}^{2+}$ handling may have substantial overlap with those in LQTS.

\section{LQT2}

Notably, $I_{\mathrm{Ks}}$ and $I_{\mathrm{Kr}}$ have minimal roles in repolarization in rodents [6]. Therefore, the studies using large animal models of LQT1 and LQT2 provide vital opportunities to delineate arrhythmia mechanisms and potential role of changes in $\mathrm{Ca}^{2+}$ homeostasis secondary to mutation-induced AP prolongation [3]. Transgenic rabbits overexpressing LQT2-linked mutant KCNH2 (HERG-G628S) in the heart exhibited significant AP prolongation and high incidence of $\mathrm{SCD}(>50 \%$ at 1 year) due to polymorphic VT, recapitulating human LQTS [11]. Experiments using isolated ventricular myocytes from LQT2 hearts revealed decrease in $\mathrm{SR} \mathrm{Ca}^{2+}$ content and $\mathrm{Ca}^{2+}$ transient amplitude, particularly noticeable under $\beta$-adrenergic stimulation [77]. Further analysis showed unchanged $I_{\mathrm{Ca}}$ and NCX1 function, while SR SERCa-mediated $\mathrm{Ca}^{2+}$ uptake and RyR2mediated $\mathrm{SR} \mathrm{Ca}^{2+}$ leak were accelerated in LQT2 ventricular myocytes. Increased SERCa activity in LQT2 has been attributed to an increase in PKA PLB phosphorylation under baseline conditions [77]. Typically SERCa activity is reduced in HF; however, increased PLB phosphorylation was previously reported in a rabbit pressure-overload-induced model of HF [20]. Enhanced RyR2 activity in LQTS has been ascribed to an increase in PKA and CaMKII phosphorylation of the channel due to the loss of phosphatases PP1 and PP2a from the complex. Identical results were reported earlier in rabbit and canine HF models $[1,5]$.

Enhanced RyR2-mediated loss of SR $\mathrm{Ca}^{2+}$ during diastole facilitates NCX1-mediated $\mathrm{Ca}^{2+}$ removal to balance increased LTCC-mediated influx during longer AP [6]. More active SERCa plays a primary role in shortening the $\mathrm{Ca}^{2+}$ transient during AP plateau when membrane potentials are close to NCX1 reversal potential. Together, these events prevent a substantial increase in $\mathrm{Ca}^{2+}$ transient amplitude in LQT2 ventricular myocytes under basal conditions, in contrast to pharmacological $I_{\mathrm{Kr}}$ block. However, in the presence of $\beta$ adrenergic agonist isoproterenol, enhanced RyR 2 activity becomes the major contributor to triggered activity in the form of arrhythmogenic EADs [67]. Stabilization of RyR2 function by pharmacological inhibition of CaMKII is sufficient to completely alleviate $\mathrm{Ca}^{2+}$-dependent afterdepolarizations in 
LQT2 ventricular myocytes [67]. Partial inhibition of NCX1 activity either directly by using pharmacological NCX inhibitor SEA400 [55] or indirectly by blocking Late $I_{\mathrm{Na}}$ with GS967 [37] also effectively eliminates EADs in this model. However, chronic use of NCX1 or $I_{\mathrm{NaL}}$ inhibitors for arrhythmia prevention in LQT2 requires extensive testing to ensure no adverse effects of such treatments.

The data whether or LQT1 or 2 induces subcellular structural remodeling is lacking. However, proteomics analysis demonstrated significant changes in expression levels and activities of enzymes involved in ATP generation via glucose utilization and fatty acids $\beta$-oxidation pathways [38], suggesting increased energy demand and increased supply in LQT1 and LQT2 transgenic rabbit hearts.

\section{LQT3}

LQT3 is associated with $S C N 5 A$ gain-of-function mutations that impede inactivation of the channel, leading to increased $I_{\mathrm{NaL}}[3,11,41]$. Unlike most LQTS, arrhythmia episodes in LQT3 occur during sleep or rest in the absence of increased catecholaminergic tone. A decrease in heart rhythm provokes profound lengthening of AP and increases incidence of tdP and polymorphic VTs in human patients. Pharmacological $I_{\mathrm{NaL}}$ enhancement to model LQT3 in rabbit ventricular myocytes induces intracellular $\mathrm{Na}^{+} / \mathrm{Ca}^{2+}$ overload, which accelerates mitochondrial ROS production [78]. Increased ROS leads to oxidation and thereby activation of CaMKII. Activated CaMKII phosphorylates RyR2 increasing its activity, which underlies an increase in pro-arrhythmic spontaneous $\mathrm{Ca}^{2+}$ release. In this work, both antioxidants and CaMKII inhibition restored diminished $\mathrm{Ca}^{2+}$ transients and reduced diastolic $\left[\mathrm{Ca}^{2+}\right]$ and spontaneous $\mathrm{Ca}^{2+}$ waves, similar to the effects in mouse ventricular myocytes with pressureoverload induced HF [78]. Experiments using LQT3 mutation mouse models suggest that increased $I_{\mathrm{NaL}}$ increases $\mathrm{SR} \mathrm{Ca}{ }^{2+}$ load and this increase promotes arrhythmogenic spontaneous waves [46]. Interestingly, in mice with LQT3 evoked by deletion residues $1510-1512(\Delta \mathrm{QKP})$ in the Scn $5 a$ gene, SERCa activity was depressed due to increased PLB expression and its reduced phosphorylation [58]. Furthermore, NCX1 expression and activity were unaltered. This is an interesting finding because $\mathrm{Na}^{+}$overload is expected to impede forward mode NCX1. The simplest explanation of these phenomena is that $I_{\mathrm{NaL}}$ enhancement is insufficient to significantly alter intracellular $\left[\mathrm{Na}^{+}\right]$despite the profound effect on APD. If this is the case, prolonged LTCC-mediated $\mathrm{Ca}^{2+}$ influx during the long AP is sufficient to increase $\mathrm{SR} \mathrm{Ca}^{2+}$ content in LQT3. Indeed, mouse models of LQT8 (Timothy Syndrome) linked to LTCC gain-of-function mutations in CACNAIC also show increase in $\mathrm{SR} \mathrm{Ca}^{2+}$ content and increased frequency of spontaneous $\mathrm{Ca}^{2+}$ waves in ventricular myocytes [26]. Remarkably, in the Scn5a $\triangle$ QKP LQT3 model, RyR2 phosphorylation remained unchanged and no evidence of enhanced activity of the channel was presented despite an increase in spontaneous $\mathrm{Ca}^{2+}$ waves [58], which is not the case in HF. However, LQT3 $\mathrm{Ca}^{2+}$ transients exhibited longer time-to-peak, suggesting subcellular dyadic structural remodeling: a hallmark of HF.

Notably, to our knowledge, a large animal model of hereditary LQT3 is yet to be created. Given substantial differences in $\mathrm{Ca}^{2+}$ cycling patterns between mice and larger animals, mechanisms of secondary remodeling uncovered in mice may differ greatly than those in humans. In small rodents, an increase in stimulation frequency decreases $\mathrm{Ca}^{2+}$ transient amplitude, e.g., a negative staircase. In rabbits or humans, increased stimulation frequency increases $\mathrm{Ca}^{2+}$ transients [6]. Accordingly, the SR loses $\mathrm{Ca}^{2+}$ at slower rates due to higher NCX1 activity and lower SERCa activity in large animals and humans vs mice. Therefore, given that arrhythmia episodes in human LQT3 patients are prevalent during slower heart rates and assuming that spontaneous $\mathrm{Ca}^{2+}$ release is a key element of trigger [58], there is a good chance that SERCa activity is increased, in stark contrast to mice. Indeed, Xiao Yan Qi et al. [66] showed enhanced SERCa activity and PLB phosphorylation due to enhanced activity of CaMKII in rabbit hearts with slowed heart rate induced by AV block 2 weeks after the procedure. At the cellular level, bradycardia was accompanied by AP prolongation resulting in enhanced LTCCmediated $\mathrm{Ca}^{2+}$ influx, increased $\mathrm{SR} \mathrm{Ca}^{2+}$ load, increased $\mathrm{Ca}^{2+}$ transient amplitude, increased contraction, and importantly, arrhythmogenic EADs at very slow pacing rates in the absence of $\beta$-adrenergic stimulation. At higher stimulation rates, presence of $\beta$-agonist was necessary for EADs induction.

\section{Other inherited arrhythmia syndromes}

The list of genes associated with LQTS is rapidly expanding. Although most of these genes encode proteins that regulate $\mathrm{K}^{+}$ and $\mathrm{Na}^{+}$conductance, the list of mutations in genes directly involved in $\mathrm{Ca}^{2+}$ handling that manifest as LQTS continues to grow. Calm1, Calm2, Calm3, TRDN, and TECRL (LQT14 18) are recent additions to the CACNA1C gain-of-function mutations associated with LQT8 [2, 24, 26, 41, 58] (Fig. 1). Although much remains to be done to delineate specific mechanism underlying electrical defects triggered by these mutations, it is unequivocally obvious how tightly changes in electrical activity are coupled with changes in $\mathrm{Ca}^{2+}$ handling. Furthermore, the key roles of secondary to initial insult $\mathrm{Ca}^{2+}$ remodeling become widely recognized in other forms of hereditary arrhythmias including Arrhythmogenic Right Ventricular Hypertrophy [21] and Brugada Syndrome [57]. 


\section{Perspective}

Sudden cardiac death remains a major health problem in the postindustrial world. Over the last quarter of century, significant progress has been made in identification of genetic components of malignant cardiac arrhythmia and improved diagnostics. This lead to rapid development of effective therapies; however, further advancement in this area requires a significantly new level of mechanistic understanding. The body of evidence accumulated over the last decade provided strong foundation for a new paradigm-shifting concept when it became obvious that the impact of a single point mutation goes far beyond elementary modification of a certain enzyme or ion channel function. Instead, mutation can induce systemic changes affecting numerous cellular signaling cascades, energy production, protein expression and degradation, and $\mathrm{Ca}^{2+}$ homeostasis. This remodeling, in an attempt to provide longterm preservation of basic contractile cardiac function, ultimately exacerbates arrhythmic potential under certain conditions such as stress. Notably, since the main goal is the same, i.e., preservation of contractile function, remodeling pathways evoked by arrhythmogenic mutations in genes encoding

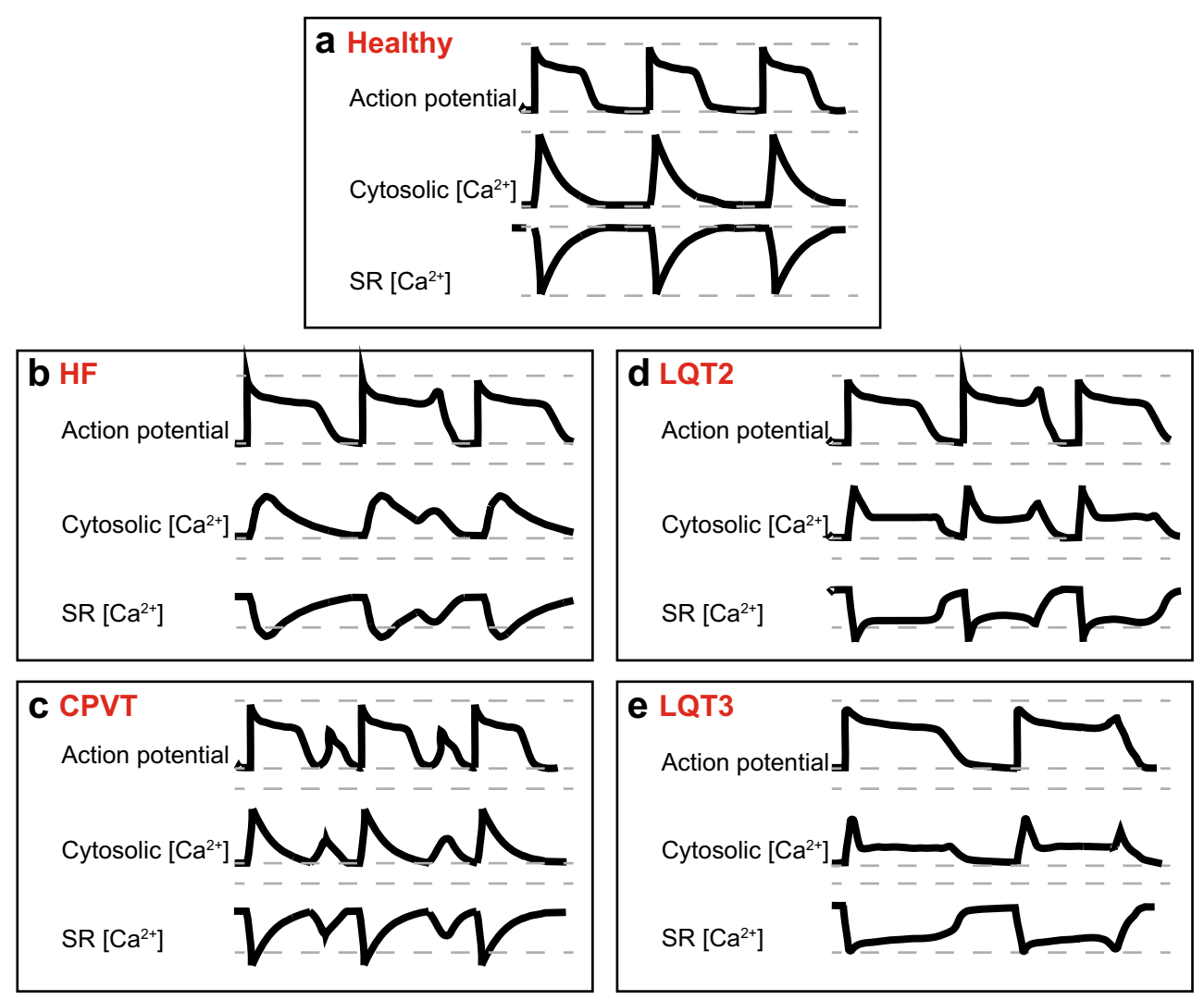

Fig. 2 Comparison of proarrhythmic changes in action potentials and $\mathrm{Ca}^{2+}$ homeostasis in HF, CPVT, and LQTS 2 and 3 ventricular myocytes. a Schematic of action potentials, $\mathrm{Ca}^{2+}$ transients, and changes in intra-SR $\mathrm{Ca}^{2+}$ in a healthy human ventricular myocyte under $\beta$-adrenergic stimulation. Grey dashed lines indicate minimum and maximum $\mathrm{Ca}^{2+}$ levels reached in healthy myocytes. b In HF, APD is prolonged due to decrease in $\mathrm{K}^{+}$currents and increase in late $I_{\mathrm{Na}} \cdot \mathrm{Ca}^{2+}$ dependent EADs/DADs underlie arrhythmogenesis under $\beta$-adrenergic stimulation. Enhanced sensitivity of RyR2 to intra-SR $\left[\mathrm{Ca}^{2+}\right]$ due to increased phosphorylation and oxidation of the channel leads to termination of systolic $\mathrm{Ca}^{2+}$ release at reduced intra-SR $\left[\mathrm{Ca}^{2+}\right]$. Faster RyR2mediated SR $\mathrm{Ca}^{2+}$ leak and reduced refractoriness of RyR2 also contributes to the enhanced propensity for proarrhythmic spontaneous $\mathrm{Ca}^{2+}$ release. Enhanced NCX1 activity, depressed SERCa activity and SR $\mathrm{Ca}^{2+}$ leak underlie reduced intra-SR $\left[\mathrm{Ca}^{2+}\right]$ and diminished $\mathrm{Ca}^{2+}$ transient amplitude. Loss of dyadic contacts between T-tubular LTCCs and jSR RyR2s impedes $\mathrm{Ca}^{2+}$ transient rise. $\mathbf{c}$ Under $\beta$-adrenergic stimulation, CPVT myocytes exhibit spontaneous $\mathrm{Ca}^{2+}$ release via defective RyR2 complexes, leading to reduced $\mathrm{Ca}^{2+}$ transient amplitude and reduced intra-SR $\left[\mathrm{Ca}^{2+}\right]$. Posttranslational remodeling, mitochondrial

dysfunction, and subcellular structural remodeling contribute to the hyperactivity of RyR2 caused by CPVT-associated mutations. Proarrhythmic activity of RyR2 drives NCX1 activity, causing a depolarizing inward current and DADs. Uncoupling of LTCCs and RyR2s due to dyad remodeling may increase $\mathrm{Ca}^{2+}$ transient rise time and reduce $\mathrm{LTCC} \mathrm{Ca}{ }^{2+}$-dependent inactivation which can result in longer APD. d In LQT2, loss-of-function mutation in $\mathrm{KCNH} 2$ reduces outward $I_{\mathrm{Kr}}$ and prolongs APD during $\beta$-adrenergic stimulation. $\mathrm{SR} \mathrm{Ca}^{2+}$ leak is accelerated due to hyperphosphorylation of RyR2. SERCa-mediated SR $\mathrm{Ca}^{2+}$ uptake is accelerated at baseline due to PLB phosphorylation. Enhanced activity of hyperphosphorylated RyR2s contributes to a reduction of SR $\left[\mathrm{Ca}^{2+}\right], \mathrm{Ca}^{2+}$ transients amplitude, and arrhythmogenic EADs under $\beta$-adrenergic stimulation. e In LQT3, gain-of-function mutation in SCN5A increases inward late $I_{\mathrm{Na}}$ and prolongs APD. Arrhythmogenic activity occurs at rest, in the absence of $\beta$-adrenergic stimulation. Longer APD increases LTCC-mediated $\mathrm{Ca}^{2+}$ influx. $\mathrm{Na}^{+} / \mathrm{Ca}^{2+}$ overload and increased activity of SERCa due to PLB phosphorylation underlies increase in $\mathrm{SR} \mathrm{Ca}^{2+}$ content, $\mathrm{Ca}^{2+}$ transient amplitude, and spontaneous RyR2mediated $\mathrm{Ca}^{2+}$ release thereby EADs at slow rates 
proteins involved in $\mathrm{Ca}^{2+}$ transport, cell electrical activity, or structural elements that underlie cardiac conduction often converge, bearing resemblance of those in structural heart disease and each other (see Fig. 2).

Given that arrhythmia syndromes are accompanied by cell systems remodeling, there is great promise in expansion of classical reductionist approaches with rapidly developing new techniques including proteomics, transcriptomics, metabolomics, and big data analytical tools to identify druggable nodes. This is expected to facilitate development of brand new classes of antiarrhythmic agents with improved efficacy and reduced adverse effects. The understanding that remodeling secondary to initial insult caused by a specific mutation has an enormous impact on arrhythmogenesis points to a necessity for expanded genetic screening panels of patients with idiopathic arrhythmias to a new level far beyond classical suspects. Also, although valuable information is being obtained generated using patient-induced pluripotent stem cell (iPSC)derived cardiomyocytes, this experimental platform needs further development to ensure the highest maturation degree of subcellular structure, metabolic, and signaling cascades, given their key roles in revealing arrhythmogenic phenotype [42]. Finally, the value in future development of engineered tissues and large animal models of hereditary arrhythmias to study mechanisms and test antiarrhythmic therapies cannot be overstated.

Funding This work was supported by the Ohio State University President's Postdoctoral Scholars Award (SH) and NIH NHLBI R01HL142588 (DT).

\section{Compliance with ethical standards}

Conflict of interest The authors declare that they have no conflict of interest.

Open Access This article is licensed under a Creative Commons Attribution 4.0 International License, which permits use, sharing, adaptation, distribution and reproduction in any medium or format, as long as you give appropriate credit to the original author(s) and the source, provide a link to the Creative Commons licence, and indicate if changes were made. The images or other third party material in this article are included in the article's Creative Commons licence, unless indicated otherwise in a credit line to the material. If material is not included in the article's Creative Commons licence and your intended use is not permitted by statutory regulation or exceeds the permitted use, you will need to obtain permission directly from the copyright holder. To view a copy of this licence, visit http://creativecommons.org/licenses/by/4.0/.

\section{References}

1. Ai X, Curran JW, Shannon TR, Bers DM, Pogwizd SM (2005 Dec 9) $\mathrm{Ca} 2+/$ calmodulin-dependent protein kinase modulates cardiac ryanodine receptor phosphorylation and sarcoplasmic reticulum Ca2+ leak in heart failure. Circ Res 97(12):1314-1322. https://doi.org/10.1161/01.RES.0000194329.41863.89

2. Altmann HM, Tester DJ, Will ML, Middha S, Evans JM, Eckloff BW, Ackerman MJ (2015 Jun 9) Homozygous/compound heterozygous triadin mutations associated with autosomal-recessive longQT syndrome and pediatric sudden cardiac arrest: elucidation of the triadin knockout syndrome. Circulation. 131(23):2051-2060. https://doi.org/10.1161/CIRCULATIONAHA.115.015397

3. Baczkó I, Hornyik T, Brunner M, Koren G, Odening KE (2020 Jun 5) Transgenic rabbit models in proarrhythmia research. Front Pharmacol 11:853. https://doi.org/10.3389/fphar.2020.00853

4. Bassani JW, Bassani RA, Bers DM (1994 Apr 15) Relaxation in rabbit and rat cardiac cells: species-dependent differences in cellular mechanisms. J Physiol 476(2):279-293. https://doi.org/10.1113/ jphysiol.1994.sp020130

5. Belevych AE, Sansom SE, Terentyeva R, Ho HT, Nishijima Y, Martin MM, Jindal HK, Rochira JA, Kunitomo Y, Abdellatif M, Carnes CA, Elton TS, Györke S, Terentyev D (2011) MicroRNA-1 and -133 increase arrhythmogenesis in heart failure by dissociating phosphatase activity from RyR2 complex. PLoS One 6(12): e28324. https://doi.org/10.1371/journal.pone.0028324

6. Bers DM. Excitation-contraction coupling and cardiac contractile force. 2001, Springer, $2^{\text {nd }}$ Edition, Volume 237 ISBN : 978-07923-7158-8

7. Bezzerides VJ, Caballero A, Wang S, Ai Y, Hylind RJ, Lu F, Heims-Waldron DA, Chambers KD, Zhang D, Abrams DJ, Pu WT (2019 Jul 30) Gene therapy for catecholaminergic polymorphic ventricular tachycardia by inhibition of $\mathrm{Ca} 2+/$ calmodulin-dependent kinase II. Circulation. 140(5):405-419. https://doi.org/10. 1161/CIRCULATIONAHA.118.038514

8. Bongianino R, Denegri M, Mazzanti A, Lodola F, Vollero A, Boncompagni S, Fasciano S, Rizzo G, Mangione D, Barbaro S, Di Fonso A, Napolitano C, Auricchio A, Protasi F, Priori SG (2017 Aug 18) Allele-specific silencing of mutant mRNA rescues ultrastructural and arrhythmic phenotype in mice carriers of the R4496C mutation in the ryanodine receptor gene (RYR2). Circ Res 121(5):525-536. https://doi.org/10.1161/CIRCRESAHA.117. 310882

9. Boyman L, Chikando AC, Williams GSB, Khairallah RJ, Kettlewell S, Ward CW, Smith GL, Kao JPY, Lederer WJ (2014 Sep 16) Calcium movement in cardiac mitochondria. Biophys J 107(6):1289-1301. https://doi.org/10.1016/j.bpj.2014.07.045

10. Brand MD (2016 Nov) Mitochondrial generation of superoxide and hydrogen peroxide as the source of mitochondrial redox signaling. Free Radic Biol Med 100:14-31. https://doi.org/10.1016/j. freeradbiomed.2016.04.001

11. Brunner M, Peng X, Liu GX, Ren XQ, Ziv O, Choi BR, Mathur R, Hajjiri M, Odening KE, Steinberg E, Folco EJ, Pringa E, Centracchio J, Macharzina RR, Donahay T, Schofield L, Rana N, Kirk M, Mitchell GF, Poppas A, Zehender M, Koren G (2008 Jun) Mechanisms of cardiac arrhythmias and sudden death in transgenic rabbits with long QT syndrome. J Clin Invest 118(6):2246-2259. https://doi.org/10.1172/JCI33578

12. Bryant SM, Kong CHT, Watson J, Cannell MB, James AF, Orchard CH (2015 Sep) Altered distribution of ICa impairs Ca release at the $\mathrm{t}$-tubules of ventricular myocytes from failing hearts. J Mol Cell Cardiol 86:23-31. https://doi.org/10.1016/j.yjmcc.2015. 06.012

13. Cacheux M, Fauconnier J, Thireau J, Osseni A, Brocard J, RouxBuisson N, Brocard J, Fauré J, Lacampagne A, Marty I (2020 Jan 8) Interplay between Triadin and Calsequestrin in the pathogenesis of CPVT in the mouse. Mol Ther 28(1):171-179. https://doi.org/10. 1016/j.ymthe.2019.09.012

14. Carr AN, Schmidt AG, Suzuki Y, del Monte F, Sato Y, Lanner C, Breeden K, Jing SL, Allen PB, Greengard P, Yatani A, Hoit BD, Grupp IL, Hajjar RJ, DePaoli-Roach AA, Kranias EG (2002 Jun) 
Type 1 phosphatase, a negative regulator of cardiac function. Mol Cell Biol 22(12):4124-4135. https://doi.org/10.1128/mcb.22.12. 4124-4135.2002

15. Cerrone M, Napolitano C, Priori SG (2009 Nov) Catecholaminergic polymorphic ventricular tachycardia: a paradigm to understand mechanisms of arrhythmias associated to impaired $\mathrm{Ca}(2+)$ regulation. Heart Rhythm 6(11):1652-1659. https:// doi.org/10.1016/j.hrthm.2009.06.033

16. Chen X, Piacentino V 3rd, Furukawa S, Goldman B, Margulies $\mathrm{KB}$, Houser SR (2002 Sep 20) L-type $\mathrm{Ca}^{2+}$ channel density and regulation are altered in failing human ventricular myocytes and recover after support with mechanical assist devices. Circ Res 91(6):517-524. https://doi.org/10.1161/01.res.0000033988.13062. $7 \mathrm{c}$

17. Chopra N, Yang T, Asghari P, Moore ED, Huke S, Akin B, Cattolica RA, Perez CF, Hlaing T, Knollmann-Ritschel BE, Jones LR, Pessah IN, Allen PD, Franzini-Armstrong C, Knollmann BC (2009 May 5) Ablation of triadin causes loss of cardiac Ca2+ release units, impaired excitation-contraction coupling, and cardiac arrhythmias. Proc Natl Acad Sci U S A 106(18):7636-7641. https://doi.org/10.1073/pnas.0902919106

18. Cooper LL, Li W, Lu Y, Centracchio J, Terentyeva R, Koren G, Terentyev D (2013 Dec 1) Redox modification of ryanodine receptors by mitochondria-derived reactive oxygen species contributes to aberrant Ca2+ handling in ageing rabbit hearts. J Physiol 591(23): 5895-5911. https://doi.org/10.1113/jphysiol.2013.260521

19. Csordás G, Thomas AP, Hajnóczky G (2001 Oct) Calcium signal transmission between ryanodine receptors and mitochondria in cardiac muscle. Trends Cardiovasc Med. 11(7):269-275. https://doi. org/10.1016/s1050-1738(01)00123-2

20. Currie S, Smith GL (1999 Jan) Enhanced phosphorylation of phospholamban and downregulation of sarco/endoplasmic reticulum Ca2+ ATPase type 2 (SERCA 2) in cardiac sarcoplasmic reticulum from rabbits with heart failure. Cardiovasc Res 41(1):135-146. https://doi.org/10.1016/s0008-6363(98)00241-7

21. Delmar M, McKenna WJ (2010 Sep 17) The cardiac desmosome and arrhythmogenic cardiomyopathies: from gene to disease. Circ Res 107(6):700-714. https://doi.org/10.1161/CIRCRESAHA.110. 223412

22. Despa S, Bers DM (2013 Aug) $\mathrm{Na}^{+}$transport in the normal and failing heart - remember the balance. J Mol Cell Cardiol 61:2-10. https://doi.org/10.1016/j.yjmcc.2013.04.011

23. Despa S, Islam MA, Weber CR, Pogwizd SM, Bers DM (2002 May 28) Intracellular $\mathrm{Na}(+)$ concentration is elevated in heart failure but $\mathrm{Na} / \mathrm{K}$ pump function is unchanged. Circulation. 105(21): 2543-2548. https://doi.org/10.1161/01.cir.0000016701.85760.97

24. Devalla HD, Gélinas R, Aburawi EH, Beqqali A, Goyette P, Freund C, Chaix MA, Tadros R, Jiang H, Le Béchec A, MonshouwerKloots JJ, Zwetsloot T, Kosmidis G, Latour F, Alikashani A, Hoekstra M, Schlaepfer J, Mummery CL, Stevenson B, Kutalik Z, de Vries AA, Rivard L, Wilde AA, Talajic M, Verkerk AO, Al-Gazali L, Rioux JD, Bhuiyan ZA, Passier R., TECRL, a new life-threatening inherited arrhythmia gene associated with overlapping clinical features of both LQTS and CPVT. EMBO Mol Med. 2016 Dec 1;8(12):1390-1408. doi: https://doi.org/10.15252/emmm. 201505719

25. Di Pasquale E, Lodola F, Miragoli M, Denegri M, Avelino-Cruz JE, Buonocore M, Nakahama H, Portararo P, Bloise R, Napolitano C, Condorelli G, Priori SG (2013 Oct 10) CaMKII inhibition rectifies arrhythmic phenotype in a patient-specific model of catecholaminergic polymorphic ventricular tachycardia. Cell Death Dis 4(10): e843. https://doi.org/10.1038/cddis.2013.369

26. Drum BM, Dixon RE, Yuan C, Cheng EP, Santana LF (2014 Jan) Cellular mechanisms of ventricular arrhythmias in a mouse model of Timothy syndrome (long QT syndrome 8). J Mol Cell Cardiol 66:63-71. https://doi.org/10.1016/j.yjmcc.2013.10.021
27. Edwards JN, Blatter LA (2014 Jul) Cardiac alternans and intracellular calcium cycling. Clin Exp Pharmacol Physiol 41(7):524-532. https://doi.org/10.1111/1440-1681.12231

28. Eisner DA, Caldwell JL, Kistamás K, Trafford AW (2017 Jul 7) Calcium and excitation-contraction coupling in the heart. Circ Res 121(2):181-195. https://doi.org/10.1161/CIRCRESAHA.117. 310230

29. Feno S, Rizzuto R, Raffaello A, Vecellio RD (2020) The molecular complexity of the mitochondrial calcium uniporter. Cell Calcium 93:102322. https://doi.org/10.1016/j.ceca.2020.102322

30. Guo T, Gillespie D, Fill M (2012) Ryanodine receptor current amplitude controls Ca2+ sparks in cardiac muscle. Circ Res 111(1): 28-36. https://doi.org/10.1161/CIRCRESAHA.112.265652

31. Hamilton S, Terentyev D. Proarrhythmic remodeling of calcium homeostasis in cardiac disease; Implications for diabetes and obesity Front Physiol 2018 Oct 30;9:1517. doi: https://doi.org/10.3389/ fphys.2018.01517. eCollection 2018

32. Hamilton S, Terentyev D (2019 May 14) Altered intracellular calcium homeostasis and arrhythmogenesis in the aged heart. Int J Mol Sci 20(10):2386. https://doi.org/10.3390/ijms20102386

33. Hamilton S, Terentyeva R, Kim TY, Bronk P, Clements RT, OUchi J, Csordas G, Choi BR, Terentyev D (2018 Dec 21) Pharmacological modulation of mitochondrial $\mathrm{Ca}^{2+}$ content regulates sarcoplasmic reticulum $\mathrm{Ca}^{2+}$ release via oxidation of the ryanodine receptor by mitochondria-derived reactive oxygen species. Front Physiol 9:1831. https://doi.org/10.3389/fphys.2018. 01831

34. Hamilton S, Terentyeva R, Martin B, Perger F, Li J, Stepanov A, Bonilla IM, Knollmann BC, Radwański PB, Györke S, Belevych AE, Terentyev D (2020 May 22) Increased RyR2 activity is exacerbated by calcium leak-induced mitochondrial ROS. Basic Res Cardiol 115(4):38. https://doi.org/10.1007/s00395-020-0797-z

35. Hasenfuss G, Reinecke H, Studer R, Meyer M, Pieske B, Holtz J, Holubarsch C, Posival H, Just H, Drexler H (1994) Relation between myocardial function and expression of sarcoplasmic reticulum $\mathrm{Ca}^{2+}$-ATPase in failing and nonfailing human myocardium. Circ Res 75:434-442

36. Hobai IA, Maack C, O'Rourke B (2004 Aug 6) Partial inhibition of sodium/calcium exchange restores cellular calcium handling in canine heart failure. Circ Res 95(3):292-299. https://doi.org/10.1161/ 01.RES.0000136817.28691.2d

37. Hwang J, Kim TY, Terentyev D, Zhong M, Kabakov AY, Bronk P, Arunachalam K, Belardinelli L, Rajamani S, Kunitomo Y, Pfeiffer Z, Lu Y, Peng X, Odening KE, Qu Z, Karma A, Koren G, Choi BR (2020 Aug) Late I(Na) blocker GS967 Supresses polymorphic ventricular tachycardia in a transgenic rabbit model of long QT type 2. Circ Arrhythm Electrophysiol 13(8):e006875. https://doi.org/10. 1161/CIRCEP.118.006875

38. Jindal HK, Merchant E, Balschi JA, Zhangand Y, Koren G (2012 Sep 18) Proteomic analyses of transgenic LQT1 and LQT2 rabbit hearts elucidate an increase in expression and activity of energy producing enzymes. J Proteome 75(17):5254-5265. https://doi. org/10.1016/j.jprot.2012.06.034

39. Kanaporis G, Blatter LA (2016 Feb 1) Calcium-activated chloride current determines action potential morphology during calcium alternans in atrial myocytes. J Physiol 594(3):699-714. https:// doi.org/10.1113/JP271887

40. Kennedy M, Bers DM, Chiamvimonvat N, Sato D (2017 Apr 1) Dynamical effects of calcium-sensitive potassium currents on voltage and calcium alternans. J Physiol 595(7):2285-2297. https://doi. org/10.1113/JP273626

41. Kistamás K, Veress R, Horváth B, Bányász T, Nánási PP, Eisner DA (2020 Feb 25) Calcium handling defects and cardiac arrhythmia syndromes. Front Pharmacol 11:72. https://doi.org/10.3389/ fphar.2020.00072 
42. Knollmann BC (2013) Induced pluripotent stem cell-derived cardiomyocytes: boutique science or valuable arrhythmia model? Circ Res 112(6):969-976. https://doi.org/10.1161/CIRCRESAHA. 112.300567 discussion 976

43. Knollmann BC, Chopra N, Hlaing T, Akin B, Yang T, Ettensohn K, Knollmann BE, Horton KD, Weissman NJ, Holinstat I, Zhang W, Roden DM, Jones LR, Franzini-Armstrong C, Pfeifer K (2006 Sep) Casq2 deletion causes sarcoplasmic reticulum volume increase, premature $\mathrm{Ca} 2+$ release, and catecholaminergic polymorphic ventricular tachycardia. J Clin Invest 116(9):2510-2520. https://doi. org/10.1172/JCI29128

44. Kobayashi S, Yano M, Uchinoumi H, Suetomi T, Susa T, Ono M, Xu X, Tateishi H, Oda T, Okuda S, Doi M, Yamamoto T, Matsuzaki M (2010 Nov) Dantrolene, a therapeutic agent for malignant hyperthermia, inhibits catecholaminergic polymorphic ventricular tachycardia in a RyR2(R2474S/+) knock-in mouse model. Circ J 74(12):2579-2584. https://doi.org/10.1253/circj.cj-10-0680

45. Lavorato M, Iyer VR, Dewight W, Cupo RR, Debattisti V, Gomez L, De la Fuente S, Zhao YT, Valdivia HH, Hajnóczky G, FranziniArmstrong C (2017 Jan 31) Increased mitochondrial nanotunneling activity, induced by calcium imbalance, affects intermitochondrial matrix exchanges. Proc Natl Acad Sci U S A 114(5):E849-E858. https://doi.org/10.1073/pnas.1617788113

46. Lemoine MD, Duverger JE, Naud P, Chartier D, Qi XY, Comtois P, Fabritz L, Kirchhof P, Nattel S (2011 Oct 1) Arrhythmogenic left atrial cellular electrophysiology in a murine genetic long QT syndrome model. Cardiovasc Res 92(1):67-74. https://doi.org/10. $1093 / \mathrm{cvr} / \mathrm{cvr} 166$

47. Little SC, Curran J, Makara MA, Kline CF, Ho HT, Xu Z, Wu X, Polina I, Musa H, Meadows AM, Carnes CA, Biesiadecki BJ, Davis JP, Weisleder N, Györke S, Wehrens XH, Hund TJ, Mohler PJ. Protein phosphatase 2A regulatory subunit B56 $\alpha$ limits phosphatase activity in the heart. Sci Signal. 2015 Jul 21;8(386): ra72. doi: https://doi.org/10.1126/scisignal.aaa5876

48. Liu N, Colombi C, Memmi M, Zissimopoulos S, Rizzi N, Negri S, Imbriani M, Napolitano C, Lai FA, Priori SG (2006 Aug 4) Arrhythmogenesis in catecholaminergic polymorphic ventricular tachycardia: insights from a RyR2 R4496C knock-in mouse model. Circ Res 99(3):292-298. https://doi.org/10.1161/01.RES. 0000235869.50747.e1

49. Liu N, Ruan Y, Denegri M, Bachetti T, Li Y, Colombi B, Napolitano C, Coetzee WA, Priori SG (2011 Jan) Calmodulin kinase II inhibition prevents arrhythmias in RyR2(R4496C+/-) mice with catecholaminergic polymorphic ventricular tachycardia. J Mol Cell Cardiol 50(1):214-222. https://doi.org/10.1016/j.yjmcc.2010. 10.001

50. Liu B, Walton SD, Ho HT, Belevych AE, Tikunova SB, Bonilla I, Shettigar V, Knollmann BC, Priori SG, Volpe P, Radwański PB, Davis JP, Györke S (2018 May 2) Gene transfer of engineered calmodulin alleviates ventricular arrhythmias in a calsequestrinassociated mouse model of catecholaminergic polymorphic ventricular tachycardia. J Am Heart Assoc 7(10):e008155. https://doi.org/ 10.1161/JAHA.117.008155

51. Loaiza R, Benkusky NA, Powers PP, Hacker T, Noujaim S, Ackerman MJ, Jalife J, Valdivia HH (2013 Jan 18) Heterogeneity of ryanodine receptor dysfunction in a mouse model of catecholaminergic polymorphic ventricular tachycardia. Circ Res 112(2): 298-308. https://doi.org/10.1161/CIRCRESAHA.112.274803

52. Lodola F, Morone D, Denegri M, Bongianino R, Nakahama H, Rutigliano L, Gosetti R, Rizzo G, Vollero A, Buonocore M, Napolitano C, Condorelli G, Priori SG, Di Pasquale E (2016 Oct 6) Adeno-associated virus-mediated CASQ2 delivery rescues phenotypic alterations in a patient-specific model of recessive catecholaminergic polymorphic ventricular tachycardia. Cell Death Dis 7(10):e2393. https://doi.org/10.1038/cddis.2016.304
53. Lu X, Ginsburg KS, Kettlewell S, Bossuyt J, Smith GL, Bers DM (2013 Feb 1) Measuring local gradients of intramitochondrial $[\mathrm{Ca}(2+)]$ in cardiac myocytes during sarcoplasmic reticulum $\mathrm{Ca}(2+)$ release. Circ Res 112(3):424-431. https://doi.org/10.1161/ CIRCRESAHA.111.300501

54. Marx SO, Reiken S, Hisamatsu Y, Jayaraman T, Burkhoff D, Rosemblit N, Marks AR (2000 May 12) PKA phosphorylation dissociates FKBP12.6 from the calcium release channel (ryanodine receptor): defective regulation in failing hearts. Cell. 101(4):365376. https://doi.org/10.1016/s0092-8674(00)80847-8

55. Milberg P, Pott C, Fink M, Frommeyer G, Matsuda T, Baba A, Osada N, Breithardt G, Noble D, Eckardt L (2008 Oct) Inhibition of the $\mathrm{Na}+\mathrm{Ca} 2+$ exchanger suppresses torsades de pointes in an intact heart model of long QT syndrome-2 and long QT syndrome3. Heart Rhythm 5(10):1444-1452. https://doi.org/10.1016/j. hrthm.2008.06.017

56. Mishina NM, Tyurin-Kuzmin PA, Markvicheva KN, Vorotnikov AV, Tkachuk VA, Laketa V, Schultz C, Lukyanov S, Belousov VV (2011 Jan 1) Does cellular hydrogen peroxide diffuse or act locally? Antioxid Redox Signal 14(1):1-7. https://doi.org/10.1089/ars. 2010.3539

57. Monasky MM, Pappone C, Piccoli M, Ghiroldi A, Micaglio E, Anastasia L (2018 Aug 10) Calcium in Brugada syndrome: questions for future research. Front Physiol 9:1088. https://doi.org/10. 3389/fphys.2018.01088

58. Montnach J, Chizelle FF, Belbachir N, Castro C, Li L, Loussouarn G, Toumaniantz G, Carcouët A, Meinzinger AJ, Shmerling D, Benitah JP, Gómez AM, Charpentier F, Baró I (2018 Oct) Arrhythmias precede cardiomyopathy and remodeling of $\mathrm{Ca}^{2+}$ handling proteins in a novel model of long QT syndrome. J Mol Cell Cardiol 123:13-25. https://doi.org/10.1016/j.yjmcc.2018.08.019

59. Moscu-Gregor A, Marschall C, Müntjes C, Schönecker A, Schuessler-Hahn F, Hohendanner F, Parwani AS, Boldt LH, Ott CE, Bennewiz A, Paul T, Krause U, Rost I (2020 Jun) Novel variants in TECRL cause recessive inherited CPVT type 3 with severe and variable clinical symptoms. J Cardiovasc Electrophysiol 31(6):1527-1535. https://doi.org/10.1111/jce. 14446

60. Niggli E, Ullrich ND, Gutierrez D, Kyrychenko S, Polakova E, Shirokova N (2013 Apr) Posttranslational modifications of cardiac ryanodine receptors: $\mathrm{Ca}(2+)$ signaling and $\mathrm{EC}$-coupling. Biochim Biophys Acta 1833(4):866-875. https://doi.org/10.1016/j.bbamcr. 2012.08.016

61. O'Rourke B, Blatter LA (2009 Jun) Mitochondrial $\mathrm{Ca}^{2+}$ uptake: tortoise or hare? J Mol Cell Cardiol 46(6):767-774. https://doi. org/10.1016/j.yjmcc.2008.12.011

62. Pan X, Philippen L, Lahiri SK, Lee C, Park SH, Word TA, Li N, Jarrett KE, Gupta R, Reynolds JO, Lin J, Bao G, Lagor WR, Wehrens XHT (2018 Sep 28) In vivo Ryr2 editing corrects catecholaminergic polymorphic ventricular tachycardia. Circ Res 123(8):953-963. https://doi.org/10.1161/CIRCRESAHA.118. 313369

63. Park SJ, Zhang D, Qi Y, Li Y, Lee KY, Bezzerides VJ, Yang P, Xia S, Kim SL, Liu X, Lu F, Pasqualini FS, Campbell PH, Geva J, Roberts AE, Kleber AG, Abrams DJ, Pu WT, Parker KK (2019 Jul 30) Insights into the pathogenesis of catecholaminergic polymorphic ventricular tachycardia from engineered human heart tissue. Circulation. 140(5):390-404. https://doi.org/10.1161/ CIRCULATIONAHA.119.039711

64. Pogwizd SM, Bers DM (2004 Feb) Cellular basis of triggered arrhythmias in heart failure. Trends Cardiovasc Med 14(2):61-66. https://doi.org/10.1016/j.tcm.2003.12.002

65. Pogwizd SM, Qi M, Yuan W, Samarel AM, Bers DM (1999 Nov 26) Upregulation of $\mathrm{Na}(+) / \mathrm{Ca}(2+)$ exchanger expression and function in an arrhythmogenic rabbit model of heart failure. Circ Res 85(11):1009-1019. https://doi.org/10.1161/01.res.85.11.1009 
66. Qi X, Yeh YH, Chartier D, Xiao L, Tsuji Y, Brundel BJ, Kodama I, Nattel S (2009 Jun) The calcium/calmodulin/kinase system and arrhythmogenic afterdepolarizations in bradycardia-related acquired long-QT syndrome. Circ Arrhythm Electrophysiol 2(3): 295-304. https://doi.org/10.1161/CIRCEP.108.815654

67. Radwański PB, Brunello L, Veeraraghavan R, Ho HT, Lou Q, Makara MA, Belevych AE, Anghelescu M, Priori SG, Volpe P, Hund TJ, Janssen PM, Mohler PJ, Bridge JH, Poelzing S, Györke $\mathrm{S}$ (2015 Apr 1) Neuronal $\mathrm{Na}^{+}$channel blockade suppresses arrhythmogenic diastolic $\mathrm{Ca}^{2+}$ release. Cardiovasc Res 106(1):143-152. https://doi.org/10.1093/cvr/cvu262

68. Schrepfer E, Scorrano L (2016 Mar 3) Mitofusins, from mitochondria to metabolism. Mol Cell 61(5):683-694. https://doi.org/10. 1016/j.molcel.2016.02.022

69. Schwarz PJ, Crotti L, Insolia R (2012 Aug 1) Long-QT syndrome: from genetics to management. Circ Arrhythm Electrophysiol 5(4): 868-877. https://doi.org/10.1161/CIRCEP.111.962019

70. Schweitzer MK, Wilting F, Sedej S, Dreizehnter L, Dupper NJ, Tian Q, Moretti A, My I, Kwon O, Priori SG, Laugwitz KL, Storch U, Lipp P, Breit A, Schnitzler MMY, Gudermann T, Schredelseker J (2017 Dec) Suppression of arrhythmia by enhancing mitochondrial $\mathrm{Ca}^{2+}$ uptake in catecholaminergic ventricular tachycardia models. JACC Basic Transl Sci 2(6):737-747. https:// doi.org/10.1016/j.jacbts.2017.06.008

71. Shannon TR, Wang F, Puglisi J, Weber C, Bers DM (2004) A mathematical treatment of integrated $\mathrm{Ca}$ dynamics within the ventricular myocyte. Biophys J 87:3351-3371. https://doi.org/10. 1529/biophysj.104.047449

72. Sies H, Berndt C, Jones DP (2017 Jun 20) Oxidative stress. Annu Rev Biochem 86:715-748. https://doi.org/10.1146/annurevbiochem-061516-045037

73. Sobie EA, Dilly KW, dos Santos CJ, Lederer WJ, Jafri MS (2002 Jul) Termination of cardiac $\mathrm{Ca}(2+)$ sparks: an investigative mathematical model of calcium-induced calcium release. Biophys $\mathrm{J}$ 83(1):59-78. https://doi.org/10.1016/s0006-3495(02)75149-7

74. Song LS, Sobie EA, McCulle S, Lederer WJ, Balke CW, Cheng H (2006 Mar 14) Orphaned ryanodine receptors in the failing heart. Proc Natl Acad Sci U S A 103(11):4305-4310. https://doi.org/10. 1073/pnas.0509324103

75. Terentyev D, Viatchenko-Karpinski S, Valdivia HH, Escobar AL, Gyorke S (2002 Sep 6) Luminal $\mathrm{Ca}^{2+}$ controls termination and refractory behavior of $\mathrm{Ca}^{2+}$-induced $\mathrm{Ca}^{2+}$ release in cardiac myocytes. Circ Res 91(5):414-420. https://doi.org/10.1161/01.res. 0000032490.04207.bd

76. Terentyev D, Györke I, Belevych AE, Terentyeva R, Sridhar A, Nishijima Y, de Blanco EC, Khanna S, Sen CK, Cardounel AJ,
Carnes CA, Györke S (2008 Dec 5) Redox modification of ryanodine receptors contributes to sarcoplasmic reticulum $\mathrm{Ca}^{2+}$ leak in chronic heart failure. Circ Res 103(12):1466-1472. https://doi. org/10.1161/CIRCRESAHA.108.184457

77. Terentyev D, Rees CM, Li W, Cooper LL, Jindal HK, Peng X, Lu Y, Terentyeva R, Odening KE, Daley J, Bist K, Choi BR, Karma A, Koren G (2014 Nov 7) Hyperphosphorylation of RyRs underlies triggered activity in transgenic rabbit model of LQT2 syndrome. Circ Res 115(11):919-928. https://doi.org/10.1161/ CIRCRESAHA.115.305146

78. Viatchenko-Karpinski S, Kornyeyev D, El-Bizri N, Budas G, Fan P, Jiang Z, Yang J, Anderson ME, Shryock JC, Chang CP, Belardinelli L, Yao L (2014 Nov) Intracellular $\mathrm{Na}^{+}$overload causes oxidation of CaMKII and leads to $\mathrm{Ca}^{2+}$ mishandling in isolated ventricular myocytes. J Mol Cell Cardiol 76:247-256. https://doi. org/10.1016/j.yjmcc.2014.09.009

79. Waggoner JR, Kranias EG (2005 Jul) Role of phospholamban in the pathogenesis of heart failure. Heart Fail Clin 1(2):207-218. https://doi.org/10.1016/j.hfc.2005.03.008

80. Wang W, Zhang H, Gao H, Kubo H, Berretta RM, Chen X, Houser SR (2010 Aug) \{beta\}1-Adrenergic receptor activation induces mouse cardiac myocyte death through both L-type calcium channel-dependent and -independent pathways. Am J Physiol Heart Circ Physiol 299(2):H322-H331. https://doi.org/10.1152/ ajpheart.00392.2010

81. Watanabe H, Chopra N, Laver D, Hwang HS, Davies SS, Roach DE, Duff HJ, Roden DM, Wilde AA, Knollmann BC

82. Wleklinski MJ, Kannankeril PJ, Knollmann BC (2020 Jul) Molecular and tissue mechanisms of catecholaminergic polymorphic ventricular tachycardia. J Physiol 598(14):2817-2834. https:// doi.org/10.1113/JP276757

83. Zhang XH, Wei H, Xia Y, Morad M. Calcium signaling consequences of RyR2 mutations associated with CPVT1 introduced via CRISPR/Cas9 gene editing in human-induced pluripotent stem cell-derived cardiomyocytes: Comparison of RyR2-R420Q, F2483I, and Q4201R. Heart Rhythm. 2020 Sep 12;S15475271(20)30889-4. doi: https://doi.org/10.1016/j.hrthm.2020.09. 007

84. Zima AV, Bovo E, Mazurek SR, Rochira JA, Li W, Terentyev D (2014 Jun) Ca handling during excitation-contraction coupling in heart failure. Pflugers Arch 466(6):1129-1137. https://doi.org/10. 1007/s00424-014-1469-3

Publisher's note Springer Nature remains neutral with regard to jurisdictional claims in published maps and institutional affiliations. 